\title{
Reflections on Provision Of Primary Education and Way Forward in Nigeria
}

\section{Ige Akindele Matthew*}

Ministry of Education, Akure, Ondo State, Nigeria

A R T I C L E I N F O

Article history:

Received 15 February

2019

Received in revised

form

29 March 2019

Accepted 18 April 2019

Available online 29 May

2019

\section{Keywords:}

reflection, provision,

education, primary

education, forward

Nigeria

\section{A B S T R A C T}

Primary education is an important stage in the education process, being the foundation for other stages. When the foundation of a building is weak, such building stands the risk of collapse in future, but will stand the test of time if it is strong. Primary education provides opportunity for a child to acquire knowledge, skills, traits, and values that can make him/her excel at the secondary and tertiary levels. Unfortunately, there are unresolved issues in its provision in Nigeria. In this paper, inadequate access to it, wastage in its provision, unstable curriculum, teaching of subjects by a teacher, unstable management, among other issues, are examined. The paper recommend the orientation of parents and guardians, strong commitment of government in funding and resource provision, among others, to salvage the situation and move primary education forward from the status quo 


\section{Introduction}

Over the years, researchers have been making frantic efforts to discover the factors influencing academic performance of pupils and students in educational institutions (Kimani, Kara., and Njagi, 2013; Kalaghor, 2016; Waseka and Simatwa, 2016; Kieti, 2017; Kipngena,2018). This is based on the fact that there is huge investment on education, by government, parents, and the private sector. To who much is therefore given, much is expected.

Among the factors influencing academic performance of pupils and students, the background prior to admission into the educational institution is notable. It is believed that a child who is academically sound i.e. with high 'Intelligent Quotient' is most likely to excel in school but vice-versa in the case of a child having poor academic background. Good academic background of a child in secondary school is thus a reflection of the quality of education exposed to at the primary level.

In Nigeria, there is growing concern about the inability of primary education to provide the expected literacy, numeracy, and communicative skills for the clients (Chinelo, 2011; Ige, 2011; Yusuf, 2009), thus giving the impression that there are challenges inherent in its provision, and that the huge investment in it is not yielding the desired results. Repositioning primary education, through the focus on the challenges in its provision thus becomes imperative.

\section{Methods}

In Nigeria, Primary education is provided for children of between the ages 6 and 12 years (National Policy on Education, 2013), in primary schools, owned by government, individual, religious organization, corporate, or Non Governmental Organisation. The duration is six years, i.e. a child starts at the age of six and completes it at the age of twelve years, provided there is no case of repetition of class during the process. Children, who attended nursery prior to admission into primary school, have an edge over those who do not have such privilege. At graduation, pupils are awarded the First School Leaving Certificate (FSLC), which, in combination with the result of Common Entrance Examination, fulfils the requirement for admission into secondary school. Presently, the curriculum of primary education in Nigeria include: Languages (English, a language of the environment and French), Mathematics, Science, Physical and Health Education, Religious Knowledge, Agriculture, Home Economics, Social Studies/Citizenship Education, Cultural and Creative Arts which include Drawing, Handicraft, Music and Cultural activities.

As indicated in the National Policy of Education (NPE, 2013), primary education has the following objectives: 1) .inculcation in a child, permanent literacy, numeracy, and ability to communicate effectively, 2) laying a sound basis for scientific, critical and reflective thinking, 3) promoting patriotism, fairness, understanding, and national unity, 4) instilling social, moral norms, and values in the child, 5) developing in the child, the ability to adapt to the changing environment; and, 6) Providing opportunities for a child to develop life manipulative skills that will enable him/her function effectively in the society within the limit of his/her capacity.

\section{Result And Discussion}

\section{Issues at Stake}

Primary education is aged in Nigeria. It started with the introduction of Christianity by the Christian Missions, in year 1842. Unfortunately, issues are at stake in the provision of this kind of education in Nigeria, such as:

\section{Inadequate access}

In Nigeria, promotion of basic education for the citizens has been a priority of government. In the past, policies, such as Universal Primary Education (UPE) was introduced and implemented in Western and Eastern regions, and later at national level (Adesina, 1977). Since 1999, Federal Government introduced Universal Basic Education programme, which has succeeded in revolutionalising the provision of this education. In spite of the opportunities, access to primary education has not been holistic. Many school-age children are not having access to it. 
Table 1. Gross Enrolment Ratio in Primary Education in Selected Countries in the World, Nigeria inclusive: 2010-2015

\begin{tabular}{ll}
\hline Country & Enrolment (\%) \\
\hline United States of America & 100.0 \\
Germany & 103.0 \\
Switzerland & 103.0 \\
Brazil & 110.0 \\
Turkey & 107.0 \\
Algeria & 119.0 \\
Gabon & 142.0 \\
Egypt & 104.0 \\
Swaziland & 113.0 \\
Morocco & 116.0 \\
X Nigeria & $\mathbf{8 5 . 0}$ \\
Togo & 125.0 \\
Kenya & 111.0 \\
Sierra Leone & 130.0 \\
\hline
\end{tabular}

Source: United Nations Development Programme (2016). Human Development Report

As indicated in Table 1, Nigeria ranked least among the countries, in terms of enrolment in primary education. A USAID report, cited in Ige (2016), indicates that out of 30 million primary school-age children in Nigeria, an estimated 10 million children are not enrolled in school. It is unfortunate that while government is clamouring for holistic access to primary education, issues, such as: high fee, being charged by private providers, early marriage practice (especially in the Northern part), poverty of parents, just to mention a few, are hindrances. As at today, the major cities in Nigeria are turgid of school-age children, who rather than being in school, are hawkers, wanderers, Area boys, motor park touts, and street children.

\section{Inadequate and unqualified Teachers}

Teacher is a formidable factor in the education of a child, because without him/her who will impact knowledge into a child, a school is incomplete. In the National Policy on Education (2013), it is indicated that for effective teaching at this level, teacher-pupil ratio shall be 1:35, that is, a teacher should be available for not more than thirty five pupils in a classroom. The situation is different in most schools, where few teachers are available to teach pupils. This is worst in the rural areas due to dearth of social amenities, poor road network, among other factors.

Table 2. Statistics on Primary Schools in Nigeria: Year 2013-2014

\begin{tabular}{llll}
\hline Year & Enrolment & Teachers & Pupil-Teacher ratio \\
\hline 2013 & $24,185,027$ & 576,665 & 42 \\
2014 & $23,129,927$ & 574,579 & 40 \\
\hline
\end{tabular}

Source: National Bureau of Statistics and Universal Basic Education Commission (UBEC) (2016), Selected Basic Public Education Statistics in Nigeria: 2013-2014

Data in Table 2 corroborates the fact that higher ratios are prevalent in most primary schools. The inadequacy of teachers is worsened by high rate of retirement of teachers from schools (Fadipe, 2000). Due to the prevailing economic downturn, coupled with the huge financial implication, government in most states, are not showing interest in the recruitment of teachers. In an attempt to cushion the effect of the inadequacy of teachers, particularly at primary level, Federal Government has been recruiting teachers, tagged "N-Power Teachers", who from observations, lack the requisite experience and commitment for the job. Quite unfortunate is the fact that many unqualified teachers, i.e. those without the basic teaching qualification (Nigeria Certificate in Education) still abound in schools. Even though there has been significant compliance with the policy stipulation in Public Primary Schools, the situation in private schools, leave much to be desired. Most private schools prefer to recruit teachers with lower qualification so as to maximize their profits. 
Table 3. Qualifications of Primary Schools Teachers in Nigeria as at 2014

\begin{tabular}{lcccc}
\hline $\begin{array}{l}\text { Graduate with } \\
\text { Teaching } \\
\text { Qualification }\end{array}$ & $\begin{array}{c}\text { Teachers } \\
\text { with NCE }\end{array}$ & $\begin{array}{c}\text { Qualified } \\
\text { Teachers }\end{array}$ & $\begin{array}{c}\text { Teachers } \\
\text { with other } \\
\text { Qualifications }\end{array}$ & $\begin{array}{c}\text { Total } \\
\text { Teachers }\end{array}$ \\
\hline 63,362 & 323,608 & 386,970 & 187,609 & 574,579 \\
\hline \multicolumn{2}{l}{ Source: Selected Basic Education Statistics in Nigeria: $2013-2014$ (2016), by National Bureau of Statistics } \\
and Universal Basic Education Commission
\end{tabular}

In Table 3, it is indicated that out of 574, 579 teachers, only 386, 970 were qualified while 187, 609 had lower qualifications (an indication that they were unqualified). The preponderance of unqualified teachers in schools, poses serious threat to the quality of education being received by the pupils, more so that it has been asserted that no educational system can rise beyond the quality of the teachers in it (National Policy on Education, by Federal Republic of Nigeria, 2013).

\section{Insufficient funding}

Adequate funding is imperative for effective management of educational institution. Educational institution needs funds for payment of salaries and allowances of teaching and non-teaching staff, procurement of stationery, facilities, and for other incidental expenses. Over the years, funding has remained a central factor in the educational system of Nigeria. Presently, funding of primary education is achieved through grant from Universal Basic Education Commission, but based on the fulfillment of certain conditions. Each state is entitled to N4.8 billion UBE grant annually. Education Trust Fund (ETF) (now TETFUND) has also been channeling 40\% of the 'Education Tax' (from 2\% tax on accessible profits of companies operating in Nigeria) on primary education. The percentage earmarked for primary education is being controlled by Universal Basic Education Commission (UBEC), and used for construction of classrooms for selected schools while the States Universal Basic Education Board (SUBEB) has been coordinating the use of funds allocated to primary education at state level. Okakwu (2015) reported that Government of Nigeria provided a total sum of N177.6 billion as total allocation to the funding of UBE programme (including primary education) between 2009 and 2014. Inspite of these funding opportunities, primary education is still not adequately funded in Nigeria, evidenced by the poor state of infrastructural facilities, instructional materials, among others, in schools.

\section{Insufficient and Poor Infrastructural facilities}

Physical facilities play important role in teaching and learning, especially at the primary school age where the sense of imagination is premature. The increase in primary school enrolment in Nigeria does not have corresponding increase in infrastructural development in schools. According to Ahmed (2003), in most primary schools teaching and learning take place under unconducive environment.

Table 4: Enrolment, Classrooms, Classroom/Enrolment Ratio, in Primary Schools in Nigeria: 2013-2014

\begin{tabular}{|l|l|l|}
\hline Enrolment & $\mathbf{2 0 1 3}$ & $\mathbf{2 0 1 4}$ \\
\hline Schools & $24,185,027$ & $23,129.927$ \\
\hline Classrooms Enrolment & 61,305 & 62,406 \\
\hline Classroom/ & 376,592 & 342,303 \\
Ratio & $1: 64$ & $1: 68$ \\
\hline
\end{tabular}

Source: Selected Basic Education Statistics in Nigeria: 2013-2014 (2016), by National Bureau of Statistics and Universal Basic Education Commission

Data in Table 4 show the enrolment, classrooms, and classroom/enrolment ratios at primary level in Nigeria, from 2013 to 2014. As indicated in the table, in 2013, there were 376,592 classrooms in 61,305 primary schools and 342, 303 in 62,406 schools in 2014. The classroom/enrolment ratio for the year was 1:64, which should be 1:40 at this level in an ideal situation. 
Table 5. Characteristics of Public Primary Schools in selected States in Nigeria: 2011 - 2012

\begin{tabular}{|c|c|c|c|c|c|}
\hline \multirow[t]{2}{*}{ State } & \multicolumn{3}{|c|}{ Percentage of usable Classrooms } & \multicolumn{2}{|c|}{ Percentage of Schools } \\
\hline & $\begin{array}{l}\text { In need of } \\
\text { urgent } \\
\text { repair }\end{array}$ & $\begin{array}{l}\text { With } \\
\text { insufficient } \\
\text { seats }\end{array}$ & $\begin{array}{l}\text { With a good } \\
\text { Chalkboard }\end{array}$ & $\begin{array}{l}\text { With classes } \\
\text { held outside }\end{array}$ & $\begin{array}{l}\text { Without } \\
\text { facility }\end{array}$ \\
\hline Jigawa & $\begin{array}{c}23 \\
(12-38)\end{array}$ & $\begin{array}{l}38 \\
(22-58)\end{array}$ & $\begin{array}{l}37 \\
(20-52)\end{array}$ & $\begin{array}{l}11 \\
(1-24)\end{array}$ & $\begin{array}{l}30 \\
(9-43)\end{array}$ \\
\hline Kano & $\begin{array}{l}19 \\
(5-47)\end{array}$ & $\begin{array}{l}68 \\
(24-81)\end{array}$ & $\begin{array}{l}40 \\
(16-93)\end{array}$ & $\begin{array}{l}56 \\
(17-82)\end{array}$ & $\begin{array}{l}58 \\
(11-91)\end{array}$ \\
\hline $\begin{array}{l}\text { Kadun } \\
\mathrm{a}\end{array}$ & $\begin{array}{l}35 \\
(14-53)\end{array}$ & $\begin{array}{l}65 \\
(16-80)\end{array}$ & $\begin{array}{l}51 \\
(30-71)\end{array}$ & $\begin{array}{l}45 \\
(8-75)\end{array}$ & $\begin{array}{l}83 \\
(19-96)\end{array}$ \\
\hline Lagos & $\begin{array}{l}34 \\
(16-54)\end{array}$ & $\begin{array}{l}29 \\
(6-56)\end{array}$ & $\begin{array}{l}34 \\
(9-51)\end{array}$ & $\begin{array}{l}7 \\
(0-22)\end{array}$ & $\begin{array}{l}30 \\
(2-73)\end{array}$ \\
\hline
\end{tabular}

Source: Annual School Census, 2011-2012 for Jigawa, Kano, Kaduna and Lagos states, cited in EDOREN- Literature on basic education

Data in table 5 reveal the gross inadequacy and poor state of infrastructure in 4 selected states in Nigeria. A school with inadequate classrooms and facilities such as chairs, lockers, libraries, textbooks, laboratories, workshop, will be uncomfortable for pupils/students to learn.

\section{Non use of Mother Tongue in Teaching}

As indicated in the National Policy on Education (2013), the medium of instruction in primary schools shall be the language of immediate environment for the first three years where English will be taught as a subject. From the fourth year, English shall progressively be used as a medium of instruction while the language of immediate environment and French, Arabic will serve as subjects. Over the years, there have been much hues and cries on the need to adopt mother tongue or language of immediate environment to teach at the elementary and primary education levels. It is being argued that the use of such language will make it easier for pupils to understand the content of lessons better, which will pay off in improved academic performance of the pupils (Ifeyinwa, 2016; David, 2008). A school of thought also views that the use of such language will not give room for quality teaching and lower the standard of education at this level, among others (Ogbonna, 2007; Olagoke, 1979, cited in Ogbonna, 2007; Nwadike, 2002, cited in Ogbonna, 2007; Alberto., Gabinet and Ranola, 2016). In spite of the arguments in favour of this idea, the status quo remains in primary schools. Children/pupils are taught using English Language. Most parents judge the standard of a school by how well their children can communicate in English Language. Some parents will not hesitate to withdraw their children from such schools and enroll them in schools with high standard of communication in English. The persistence of this situation thus continues to undermine effective teaching, proper mastery of lessons contents, as well as the quality of primary education in Nigeria.

\section{Wastage}

Wastage is an issue of concern in Nigeria's educational system. Even though it affects the entire system, primary education has been recording its share of it. While pupils are dropping out of primary schools due to institutional and non-institutional factors, many are also repeating classes due to failure in examinations (Adeyemi and Adu, 2012; Duze, 2011; FGN, 2003; Mbah, 2008, cited in Ige, 2015; Arowolo., Adedeji., Arowolo,and Adaja ( 2016). The implication of high-level wastage is that more resources are being utilized for the training of pupils at this level of the educational system.

\section{Unstable and Inappropriate Curriculum}

Curriculum is the experiences/activities (co-curricular) provided under the auspices of school to bring about a change in learner in the desired direction (Ngwu, 2008). The idea of having a curriculum for education in Nigeria, dates back to 1969 when National Curriculum Conference was inaugurated, sequel to public criticisms of the educational system inherited from the colonial governments (Ogunnu, 2000).. Since then, the curriculum of education in Nigeria has been undergoing review and improvements. In spite of these, the curriculum is laden with shortcomings (Akpan, 2008; Ukpai and Okoro, 2011; Balogun, 2009). There are complaints on the reliability of the present curriculum, introduced over a decade ago. For example, it is being argued that it is overloaded. Also, while some topics are obsolete, there are unnecessary repetition of topics and subtopics that makes teaching and learning difficult. In addition, the 
number of subjects to be taught at each level does not meet global standards (Ministry of Education, Ondo State, 2012)

According to Adamu (2017), the 9-year Basic Education Curriculum, was developed in 2006 and introduced into the system in 2008. In the curriculum, History was integrated into Social Studies. This step led to agitations by stakeholders, including the Historical Society of Nigeria. Federal Ministry of Education, which eventually culminated in the re-separation of the History from Social Studies. Prior to the advent of the new curriculum, Home Economics, Agriculture Science, Social Studies, Civic Education and Security Education, Basic Science, Basic Technology, Physical and Health Education, Information Technology, were taught separately in schools. The 9-year Basic Education Curriculum has however integrated some subjects, such as Prevocational Studies, Social Studies, Civic Education and Security Education, as National Values, Basic Science, Basic Technology, Physical and Health Education and Information Technology as Basic Science and Technology.

Table 7. Subjects in Primary Schools in Nigeria

\begin{tabular}{lll}
\hline /N & Primary 1-3 & Primary 4-6 \\
& English Studies & English Studies \\
& Mathematics & Mathematics \\
& Basic Science and Technology & Basic Science and Technology \\
& Cultural and Creative Arts & Cultural and Creative Arts \\
& History & History \\
& National Values & National Values \\
& Christian Religious Knowledge & Christian Religious Knowledge \\
& Islamic Studies & Islamic Studies \\
& One(1) Nigeria Language & Prevocational Studies \\
0 & Arabic (Optional) & French \\
2 & - & One(1) Nigeria Language \\
\hline
\end{tabular}

Source: Nigeria Educational Research and Development Council (2017). Teachers Guide for the New 9-Year Basic Education Curriculum. Abuja, Nigeria: NERDC Press

\section{Teaching of Subjects in the Curriculum, by a Teacher}

In Nigeria, the curriculum of primary education encompasses many subjects. Ordinarily, each of the subjects needs to be handled by a competent teacher, to give room for proper understanding by the pupils. As indicated in the National Policy on Education (2013), specialist teachers shall be provided for particular subjects, such as; Mathematics, Basic Science, Basic Technology, Physical and Health Education, Language Arts (in relation to English, Arabic, French, Sign Language and Nigerian Languages), Music, Fine Art, Home Economics, and Agricultural Science. Unfortunately, in most primary schools, a teacher teaches at least eight different subjects per day and throughout the five days in a week. Also, such teacher has to write eight Lesson Notes, prepare Scheme of Work for the subjects, give tests and assignments to the pupils, as well as mark the scripts daily. It is thus assumed that a teacher in primary school has better understanding of the subjects, whereas observation of the author reveals a different situation. Most teachers are fond of teaching effectively, those subjects they have proper understanding of. It is a common saying that 'you cannot give out what you do not have'. This situation is affecting the quality of teaching and learning in primary schools and creating stress for the teachers. Also, it is a fact that many teachers studied under different curriculum in tertiary institutions they attended. How the knowledge acquired under varying conditions will be applicable in the present situation, is an issue of concern. In some cases, when a teacher assigned to a particular class is unavoidably absent, it becomes difficult to find a replacement due to acute shortage of teachers in schools, which is encouraging the merging of classes and interrupted teaching.

\section{Unstable Management}

In Nigeria, primary education has been under the tutelage of different managers. It was initially controlled by the Christian Missions (1842-1882), later handled by the colonial governments (1882 to 1940s), and the regional governments (1950s). Since the attainment of independent status in 1960, it has been under the control of the federal, state, and local governments. Presently, no tier of government is willing to accept wholeheartedly, the responsibility of primary education funding and management because of the huge financial implication. It is disturbing that in Nigeria, primary education is like a football, being pushed among the players on the field (i.e. the three tiers of government). According to Oni 
(2009), poor administration has been the bane of primary education in Nigeria, which is not helped by the politics that is involved and the unstable management.

\section{Way Forward}

Moving primary education forward from the present state is imperative in Nigeria, in view of the importance of this education to individuals and nation, the concerted efforts being made to achieve the Sustainable Development Goals, as well as the challenges it is facing. The following strategies, are recommended:

\section{Improved funding}

Government should allocate more funds for implementation of the UBE programme so that additional infrastructural facilities and instructional materials can be procured, for training the pupils. The stipulated conditions for assessment of the matching grant, particularly, the payment of counterpart fund by each state government, should be reviewed, in view of the difficulty in satisfying these by state governments. Presently, many states are owning salaries of workers, thus making it difficult to afford the counterpart funds. It is a fact that government has been the major financier of education in Nigeria, primary education inclusive. Even though there have been interventions from international organizations, there is need for more of the gesture. Wealthy individuals and Old pupils, should be contacted for donation of money, sponsoring of projects in their respective schools. As a way of boosting the funding of primary education, Federal Government should seek the assistance of International Philantrophic Institutions, such as UNICEF, World Bank

\section{Proper management and accountability of funds allocated to primary education}

Funds allocated to primary education should be consolidated and judiciously utilized by the Education administrators and thus should not be regarded as 'national cake'. Cases of misappropriation of fund and fraud, should be investigated and those found to be involved, should be punished.

\section{Recruitment and training of teachers}

In view of the strategic role of teachers in education process and the level of inadequacy in primary schools in Nigeria, government should recruit additional teachers from the pool of unemployed graduates in the society and distribute them to primary schools. Government should enforce that teachers without the minimum teaching qualification (NCE) should upgrade their qualification through in-service training. There should also be periodic training of teachers (old and new), through seminars, workshops and conferences, to improve their performance. Teachers should also be motivated to enhance their performance. For example, teachers in the rural areas should be paid additional allowance, to encourage them and reduce the rate of their movement to the urban areas. Teachers should also be regularly sponsored for seminars, conferences, and workshops, to encourage them and improve their productivity.

\section{Enforcing Rotational Teaching in Schools}

It is high time for government to take decisive action against the issue of allowing a single teacher to teach all subjects in the curriculum. Rotational teaching should be adopted and enforced in primary schools. This is an arrangement where a teacher who is a specialist in a particular subject will be allowed to teach pupils and after, give room for others to do so, as applicable in secondary schools. This will enable the pupils to understand the rudiments of lessons, which will pay off improved academic performance of the pupils.

\section{Enforcing the use of Mother Tongue in Teaching in schools}

Government should enforce the use of mother tongue or language of the immediate environment in teaching in primary schools across the states of the country. Ministry of Education and other agencies in charge of monitoring of schools should be fortified and made to be committed to routine and regular monitoring of schools. Appropriate sanction should be meted on schools that fail to comply with the policy.

\section{Review of Curriculum}

Even though government is not relenting in its effort to review curriculum of education at all levels, the review of primary education curriculum is imperative in view of the shortcomings inherent in it. Such review should however be a regular process. 


\section{Curbing Wastage}

In view its negative effects, it is imperative for government to curb wastage in the system. Government should initiate advocacy measures for parents and students through print and electronic media, and parents/guardians should be given orientation against premature withdrawal of their children from schools. As far as poverty of parents/guardians is a major factor influencing wastage in Nigeria, government should empower the artisans, traders, through loans, to be able to sponsor their children in schools. Identified children from poor homes as well as the brilliant ones, should be awarded scholarships to alleviate the effect of poverty of their parents/guardians. Government should also reintroduce education loan for pupils/students to enable poor parents pay the fees and procure needed materials for their children.

\section{Ensuring stability of its management}

Government should ensure stability in the management of primary education. Situation where it is being pushed among the three tiers of government is not a good development. Local government should assume the responsibility for its control but with a stable and reasonable allocation to it, for the purpose.

\section{Orientation of Citizens}

It is a fact that in a country where many of the citizens are illiterate, particularly, the parents, the purpose and objectives of UBE may not be understood by many of the citizens. It is thus necessary for government to orientate the citizens on the UBE programme and the need to enroll their children in schools

\section{Conclussion}

Primary education serves as the foundation for other education levels. The strategic position it occupies in the education system, necessitates serious attention to be paid to its provision. In the light of the discussions in this paper, it can be concluded that the state of primary education in Nigeria, leaves much to be desired because of the challenges it is facing, such as: wastage, inadequate and decay facilities, inadequate funding, inadequate access, unstable management curriculum, among others.

\section{Reference}

Adesina S (1977). Planning and educational development in Nigeria. Lagos: Educational Industries Nigeria Limited.

Adeyemi, T.O \& Adu, E.T (2012). Teacher's quality and internal efficiency in primary schools in Ekiti State,

Nigeria. International Journal of Academic Research in Progressive Education and Development, 1(1), 188-212

Ahmed (2003), Importance of primary and secondary education. Retrieved from http://www.friendcalib.org

Alberto, R., and Gabinete, S and Rañola, V(2016). Issues and Challenges in Teaching Mother

Tongue-Based Multilingual Education in Grades II and III: The Philippine Experience (2016). Available at SSRN: https://ssrn.com/abstract=2768558 or http://dx.doi.org/10.2139/ssrn.2768558

Akpan BB (2008, 23rd-26th August). Nigeria and the future of Science Education. Paper Presented at the 51st Science Teachers Association of Nigeria Conference, held at Akure, Nigeria All Nigeria Conference of Principals of Secondary Schools (2010, February, 22nd-26th). Comunique at the end of the National Executive Council (NEC) meeting, held at Abeokuta, Nigeria.

Arowolo, A.A., Arowolo, E., Ajaja, A, and Joseph, I (2016). Trend analysis of Students Dropout

Rate and the effects on the Social and Educational Systems in Nigeria. International Journal of Latest Research in Engineering and Technology, 2 (4): 08-16 
Balogun F.A (2009). Structure of nine (9)-year Basic Education Curriculum. Paper Presented at a Workshop organized by Ministry of Education for Education Officers in Ondo State.

Chinelo OD (2011). Falling standard in Nigeria education: Traceable to Proper Skills Acquisition in Schools? Educational. Research, 2(1):803-808.

David, A.O. (2008). The Impact of Mother Tongue on Students' Achievement in English

Language in Junior Certificate Examination in Western Nigeria. Journal of Social Sciences, 17(1):14-19.

Duze, C.O. (2011). Attrition Rates in Primary Schools in Delta State of Nigeria. International Journal of Education Administration and Policy Studies, 3(6), 68-77.

Fadipe,J.O (2000).Teacher retention in the school system: A strategy towards planning for quality education in Nigeria. Unpublished PhD Thesis, University of Jos, Nigeria.

Fafunwa, A.B. (1974). History of education in Nigeria. London: George Allen \& Unwin Ltd.

Federal Republic of Nigeria (2013). National Policy on Education. Abuja; NERDC.

Federal Republic of Nigeria (2003). Nigeria Demographic and Health Survey. Abuja; Federal Government Press.

Ige AM. (2011). Myths and realities of falling standard of education in Nigeria: The way forward. Nigeria Journal of Professional Teachers.(2), 36-48.

Ige, A,M. (2016).Financial allocation to education: trends, issues and way forward in Nigeria, Journal Plus Education, XIV (1), 228-243

Ifeyinwa, 0 (2016).Mother tongue education; A panacea to effective teaching and learning in Nigeria primary schools. Research in Humanities and Social Sciences,6(17),93-97

Ige A. M (2015).Wastage Factor in Universal Basic Education Programme implementation in

Nigeria: The way out. The Online Journal of Counseling and Education, 2015, 4(1), 1-12

Jaiyeoba A.O, and Atanda A.I (2003). Community participation in the provision of facilities in secondary schools in Nigeria. Paper presented at the skills improvement programme for effective performance of teachers in Nigerian schools at Ondo, Nigeria.

Kalaghor, L.D(2016).An Analysis of factors influencing Students Academic Performance in

Public and Private Secondary Schools in Rivers State, Nigeria. Journal of Education and Practice, 7(28), 96101

Kapngero, L(2018). Teacher-factors influencing Academic Performance in Secondary School Students in Physics: A study of Secondary Schools in Bureti Sub County, Kericho County, Kenya: M.ED Dissertation, MOI University, Kenya

Kieti, J.M(2017).An Investigation into factors influencing Students Academic Performance in Public Secondary Schools in Matungule Sub County, Machakos County, Kenya. M.ED Dissertation, South Eastern Kenya University

Kimani, G.N., Kara, A.M and Njagi, L.W(2013). Teacher Factors Influencing Academic Achievement in Secondary Schools in Nyandarua County, Kenya. International Journal of Education and Research,1(3). 1-14 
National Bureau of Statistics and Universal Basic Education Commission (UBEC)(2016). Selected Basic Public Education Statistics in Nigeria: 2013-2014

National Bureau of Statistics and Universal Basic Education Commission (2016). Selected Basic

Education Statistics in Nigeria. Abuja: NBS and UBEC

Ngwu AN (2008, August). Current Issues in Implementation of primary School Science Curriculum in Nigeria. Paper presented at the 49th Annual Conference of Science Teachers Association of Nigeria, held at Yenagoa, Bayelsa State.

Nigeria Educational Research and Development Council (2017). Teachers Guide for the New 9-Year Basic Education Curriculum. Abuja, Nigeria: NERDC Press

Ogbona, S.O(2007).Issues, problems and prospects of Mother Tongue Education in Nigeria. Journal of the Linguistic Association of Nigeria, 10, 223-232

Ogunnu MA (2000). A survey of the status of implementation of the primary School curriculum in Edo and Delta States of Nigeria. International. Journal. of Educational Planning. and Adminiistration. 1(1):28-37.

Ondo State Ministry of Education (2012). Train the trainers workshop pot e use of the Revised 9-year Basic Education Curriculum. A Workshop, organised by Ondo State Ministry of Education (being a replica of Nigeria Educational Research and Development Council, train the Teachers Workshop.

Ukpai PO, Okoro TU (2011, 23rd-26th August). Science, Technology and Mathematics (STEM)

Education in Nigeria: The need for Reforms. A paper presented at the 52nd Science Teachers Association of Nigeria Conference, held at Akure, Nigeria

United Nations Development Programme (2016). Human Development Report

Waseka, E.L., and Simitwa, E.M.W(2016). Student-factors influencing Academic Performance in Secondary Education in Kenya: A case study of Kakamega County, Kenya. Educational Research, 7(3), 72-87

Yusuf HO (2009). Strategies for improving the teaching of reading comprehension in primary Schools. Journal of Education Research and Development. 4(3):63-68 